\title{
KADERSISASI DA'I MODERAT ERA MILENIAL DI PENGURUS CABANG NAHDLATUL ULAMA KABUPATEN KENDAL
}

\author{
Abdul Kholiq \\ UIN Walisongo Semarang \\ Jl. Prof. Dr. Hamka Tambakaji, Kec. Ngaliyan, Kota Semarang \\ abdulkholiqkpi@gmail.com
}

\begin{abstract}
The da'wah cadress face a lot of challanges on hus way. The most serious one is the condition and situation of this millenial era. Inthis millenial era the ability of $D a^{\prime} I$ is demended to be harmony with the style of this generation, such as skills of internet, journalistic skills, utilizing and managing social media, blog's and mass media channel's. This challenges was also experienced by Kenadal district PCNU, then the researcher find out "how to regeneration the moderat Da'I in this millenial era at Kendal district PCNU. The method that used to collect the data is consist of observation, interview, and documentation, the result will be useful to provide new understanding for cadress practitioners about how to regeneration for moderat $D a^{\prime} I$ and can give a new awareness about caderization, build a moderate attitude, tolerance among religious people, avoid the violences against another parties based on different thought's or different religion's and maimtain the integrity of the nation.
\end{abstract}

Keywords: Cadreization, Moderate Da'i, Millennial

\begin{abstract}
Abstrak
Dalam perjalanan dakwahnya, banyak tantangan yang Kader Dakwah hadapi. Salah satu yang paling serius adalah situasi dan kondisi zaman yang kini tengah berada pada era milenial. Da'i di zaman milenial dituntut untuk bisa mengikuti gaya dan model generasi ini termasuk dalam pemanfaatan media agar tetap diterima oleh generasi milenial. Seperti kecakapan dalam memanfaatkan internet, kecakapan jurnalistik,memanfaatkan dan mengelola media sosial, blog, dan kanal-kanal media massa. Tantangan tersebut juga dialami oleh PCNU Kabupaten Kendal, sehingga peneliti terdorong untuk mengetahuibagaimana kaderisasi da'i moderat era milenial di lembaga dakwah PCNU Kabupaten Kendal. Metode yang digunakan untuk mengumpulkan data adalahPengamatan, Wawancara, dan Dokumentasi. Hasilnya akan bermanfaat untuk memberikan pemahaman baru bagi praktisi pengkaderan mengenai cara pengkaderan
\end{abstract}


da'i moderat dan dapat memberi kesadaran baru terkait kaderisasi, membangun sikap moderat, toleransi antar umat beragama, menghindari kekerasan terhadap pihak lain yang berbeda pemikiran atau berbeda agama, dan menjaga integritas bangsa.

Kata Kunci: Kaderisasi, Da'i Moderat, Milenial

\section{A. PENDAHULUAN}

Generasi milenial adalah pengguna terbanyak media komunikasi, sehingga pendekatan agama atau dakwah terhadap generasi milenial harus dilakukan melalui pemanfaatan media-media komunikasi (Azmi: 2019). Kemajuan teknologi informasi yang menyebabkan ketergantungan pada generasi milenial ini memberi dampak salah satunya berupa rusaknya norma dan aturan yang sudah ada. Sehingga menyebabkan terjadinya perubahan dan masalah sosial dan munculnya kebiasaan-kebiasaan baru (Ananda: Kompasiana.com).

Generasi milenial menjadi sorotan dan bahan diskusi disemua sisi kehidupan karena terjadi perubahan gaya hidup yang mencolok dibandingkan dengan generasi sebelumnya dalam hal sikap, ideologi, dan paham. Banyaknya aktivitas dan tindakan yang diadopsi dari budaya luar ini menjadikan sebagian pihak menyatakan bahwa generasi milenial sangat terbuka dengan teknologi. Smartphone dengan segala fitur terbaru yang ditawarkan Facebook, youtube, twiter, instagram, whatshap dan lain sebagainya merupakan media yang paling banyak digunakan oleh generasi millennial, yang dapat membawa nilai negatif ( Panindya: Kompasiana.Com)

Generasi muda milenial ini dianggap telah meninggalkan norma-norma yang berlaku di masyarakat sehingga nilai dan norma yang dulu selalu dijadikan pedoman oleh masyarakat terasa sudah hilang, termasuk adat istiadat yang bisa dijadikan kontrol sosial pun sudah tidak ditemukan lagi. Generasi milenial ini dianggap lebih mengedepankan rasionalisme dan egoism dalam menyikapi sesuatu. Masyarakat juga lebih banyak disuguhkan dengan cara-cara brutal seperti makian, cercaan, dan aksi-aksi brutal lainnya. Kondisi ini diperparah lagi setelah banyak generasi milenial ini tidak lagi menganggap nilai-nilai Ke-Islaman yang selama ini menjadi panutan. Agama dianggap sebagai sesuatu yang tertinggal atau kuno dan teknologi dianggap sebagai sesuatu yang modern dengan segala sikap dan gaya hidup yang berafiliasi ke model gaya hidup orang Barat (Hasan: 2018).

Namun demikian juga perlu dipahami bahwa kemajuan dan kecanggihan media informasi, transportasi, dan teknologi menjawab segala kebutuhan manusia masa kini. Maka akan dianggap rugi jika tidak mengikuti kemajuan teknologi tersebut. Kemajuan teknologi mampu membantu mempermudah pekerjaan karena hanya dengan menekan satu tombol baik HP, komputer maupun media elektronik lainnya maka semua pekerjaan dapat terselesaikan dengan baik. Kecanggihan-kecanggihan seperti inilah yang identik dengan generasi milenial (Widhiasmara: Kompasiana.Com). Dengan demikian bisa dipahami bahwa kemajuan teknologi yang melekat pada generasi milenial ternyata juga memberikan manfaat yang baik. 
Oleh karena itu pada masa atau era melenial ini maka diperlukan da'i yang juga memiliki pengetahuan dan kemampuan dalam pemanfaatan teknologi seperti yang dilakukan oleh anak-anak zaman melenial sehingga model dakwah yang dilakukan dapat dengan mudah diterima di kalangan milenial saat ini.

Permasalahan kaderisasi milenial yang tangguh juga dihadapi oleh PCNU (Pengurus Cabang Nahdlatul Ulama') Kabupaten Kendal, oleh karena itu rumusan masalah pada makalah ini adalah “bagaimana kaderisasi da'i moderat era milenial di lembaga dakwah PCNU Kabupaten Kendal?"

Penelitian ini diharapkan akan bermanfaat untuk memberikan pemahaman baru bagi praktisi pengkaderan mengenai cara pengkaderan da'i moderat. Bagi publik atau pembaca, diharapkan dapat memberi kesadaran baru terkait kaderisasi, membangun sikap moderat, toleransi antar umat beragama, menghindari kekerasan terhadap pihak lain yang berbeda pemikiran atau berbeda agama, dan menjaga integritas bangsa. Selain itu diharapkan masyarakat mampu meminimalisir sikap radikal yang berkembang di masyarakat.

\section{B. METODOLOGI PENELITIAN}

Jenis penelitian ini adalah penelitian kualitatif. Penelitian kualitatif merupakan penelitian yang menghasilkan data deskriptif berupa kata-kata tertulis atau lisan dari orang-orang dan perilaku yang dapat diamati (Moleong: 2012). Pendekatan penelitian ini adalah fenomenologis. Penelitian fenomenologi mencoba menjelaskan atau mengungkap makna konsep atau fenomena pengalaman yang didasari oleh kesadaran yang terjadi pada beberapa individu (Mulyana: 2010).Pada penelitian ini digunakan beberapa metode yang tepat untuk mengumpulkan data, yaitu : Observasi (pengamatan), Interview (wawancara), dan Dokumentasi.

Setelah semua data terkumpul maka dilakukan analisis dengan menggunakan analisis data menurut Miles dan Hubermen, yang mana analisis ini dilakukan secara interaktif dan berlangsung secara terus menerus sampai tuntas. Aktivitas dalam analisis data ini yaitu dengan merangkum, memilih hal-hal pokok, memfokuskan pada hal-hal yang penting untuk dicari tema dan polanya (data reduction), kemudian data disajikan dalam sebuah pola yang sesuai dengan kajian (data display), dan setelah itu ditarik sebuah kesimpulan yang menghasilkan sebuah hipotesis dan deskripsi atau gambaran suatu objek yang sebelumnya masih remang-remang atau gelap menjadi jelas (conclusion drawing) atau (verification) (Sugiyono: 2008).

\section{HASIL DAN PEMBAHASAN}

\section{Kaderisasi}

Kaderisasi dapat dimaknai sebagai proses penurunan berbagai macam bentuk nilai baik nilai umum maupun khusus oleh suatu badan atau instansi. Dalam kaderisasi terdapat berbagai materi yang diberikan, materi tersebut dapat berupa materi manajemen, materi kepemimpinan dan sebagainya, karena orang yang diberikan materi diharapkan dapat menjadi orang yang akan melanjutkan program materi 
tersebut (Muniri: 2014). Perubahan sikap dan perilaku serta proses mendewasakan adalah konsekuensi adanya kaderisasi, sehingga bagaimana bisa menciptakan kaderisasi yang intelek untuk mendekati kesempurnaan perubahan tersebut.

Menurut Pengurus Besar PMII (1998) kaderisasi memiliki peranan sebagai berikut:

a. Pewarisan nilai-nilai organisasi yang baik.

b. Penjamin keberlangsungan organisasi.

c. Sarana belajar bagi anggota.

Tujuan kaderisasi secara umum merupakan nilai atau hasil yang diharapkan dari usaha kaderisasi tersebut. Kadersisasi da'i dalam Islam, diantaranya yaitu:

a. Terbentuknya pribadi yang menghayati dan mengamalkan ajaran Islam

b. Terbentuknya pribadi yang berbudi luhur sesuai dengan syari'at Islam

c. Terbentuknya pribadi yang menguasai ilmu dan kecakapan dalam bidang tertentu

d. Terbentuknya pribadi yang mempunyai kesanggupan memimpin

e. Terbentuknya pribadi yang memiliki kesanggupan dalam menanggulangi permasalahan umat dan mengembangkan ke arah yang dicitacitakan (Pengurus Besar PMII: 1998).

2. $\mathrm{Da}^{\prime} \mathrm{i}$

Da'i merupakan kata bahasa Arab bentuk fail yang mempunyai arti yang berdakwah (Fatah: 1999). Dalam pengertian yang khusus (pengertian Islam), da'i adalah orang yang mengajak kepada orang lain baik secara langsung atau tidak langsung dengan kata-kata, perbuatan atau tingkah laku kearah kondisi yang baik atau lebih baik menurut syariat $\mathrm{Al}$ quran dan sunnah. Berdasarkan pengertian khusus tersebut da'i identik dengan orang yang melakukan amar makruf nahi munkar (Amin: 2013), teladan bagi umat sekaligus pelopor perubahan. Hal-hal yang semula menyimpang dari Al quran dan Hadits diluruskan agar sesuai dengan ajaran Islam baik aqidah, muamalah, dan aspek-aspek kehidupan lainnya.

Seorang da'i harus memenuhi kualifikasi dan syarat-syarat tertentu agar proses dakwahnya sesuai dengan target yang ingin dicapai yaitu (Najamudin: 2010)

a. Da'i harus mempunyai pengetahuan yang mendalam tentang Islam baik masalah aqidah, fiqih, muamalah dan berbagai aspek disiplin keagamaan lainya.

b. Da'i harus mengetahui seluk-beluk Islam sebelum terjun ke lapangan untuk berdakwah, sehingga mampu memberikan pemahaman tetang kesempurnaan agama Islam kepada masyarakat.

c. Da'i harus menjadi teladan yang baik bagi umatdalam hal perilaku, aktifitas, akhlak, perkataan dan perbuatan.

d. Da'i harus mempunyai kemampuan berkomunikasi yang baik. Kemampuan berkomunikasi sangat berpengaruh kepada paham tidaknya mad'u.

e. Da'i dituntut memahami ilmu psikologi kepribadian dan perkembangan. Dengan mengetahui kondisi kejiwaan masyarakat akan lebih mudah bagi da'i untuk memberikan solusi yang sesuai dengan masalah yang dihadapi, dan materi dakwah akan lebih mudah diterima. 
Keberadaanda'iharusmampumenjadi pelayan umat sekaligus sebagai agen perubahan sosial, dalam hal memberikan pencerahan kepada umat tentang agama Islam dengan syariatnya. Sebagaimana yang telah dicontohkan Rasulullah dalam dakwahnyauntuk merubah masyarakat jahiliyah menjadi ummat yang mukmin, muslim dan muhsin (Machasin: 2015).

Seorang da'imempunyai fungsi
diantaranya:

a) Meluruskan akidah.

Da'i berkewajiban mengajarkan dan meluruskan setiap keyakinan yang salah tentang ketuhanan, karena pada dasarnya akanada manusia yang menyelewengkan ajaran agama dan da'i harus mampu meluruskan ajaran ketuhanan secara benar.

b) Memotivasi umat untuk beribadah dengan baik dan benar.

Da'i berkewajiban untuk mengajak kepada umat untuk melakukan ibadah sesuai dengan syari'at secara benar sesuai ajaran agama Islam.

c) Amar ma'ruf nahi munkar.

Da'i berkewajiban untuk mengajak umat untuk melakukan kebajikan dan meninggalkan kemunkaran.

d) Menolak kebudayaan yang merusak.

Da'i harus mampu dan berani memberikan ajaran kepada umat untuk melakukan syari;at secara benar, dan harus mampu memilah adat atau kebudayaan yang tidak sesuai dengan ajaran dan hukum Islam, maka diberikan pengertian kepada umat bahwa hal itu tidak boleh dilakukan (Aliyudin: 2009).
Bekal utama seorang da'i adalah keimanandanketaqwaankepadaAllahSWT. Bekal penunjang lainnya adalah sahabatsahabat yang shalih, pembimbing yang menuntun dan memberikan pengarahan, pengalaman dan lainnya, sehingga seorang da'i bisa menemukan kekuatan tekad dan terhindar dari penyimpangan serta kekeliruan(Masyhur: 2000).

Sifat-sifat yang harus dimiliki seorang da'i dalam mendukung keberhasilan dan legitimasi pelaku dakwah sebagai berikut :

a) Harus benar-benar istiqomah dalam keimanannya dan percaya seyakinyakinnya akan kebenaran agama Islam untuk disampaikan kepada umat.

b) Harus menyampaikan dakwahnya dengan lidahnya sendiri. Da'i tidak boleh menyembunyikan kebenaran, apalagi menukar kebenaran tersebut dengan nilai harga yang rendah.

c) Menyampaikan kesaksiannya tentang kebenaran itu secara lisan maupun perbuatannya.

d) Terhadap semua golongan dan kelompok umat da'i mampu berdakwah secara jujur dan adil serta tidak terpengaruh dengan penyakit hati, seperti hasad, sombong, serakah, dan sebagainya.

e) Mempunyai niat yang ikhlas dalam berdakwah hanya karena Allah dan selalu mengharap ridla-Nya.

f) Selalu menjadikan Rasulullah sebagai teladan utama dalam segenap kehidupan baik pribadi, rumah tangga dan keluarga.

g) Mempunyai keberanian moral dalam berdakwah, namun memahami batasbatas keimanan yang jelas. 
h) Selalu mengutamakan persaudaraan dan persatuan umat, sebagai perwujudan ukhuwah Islamiyah.

i) Mempunyai sifat terbuka, penuh toleransi, lapang dada dan tidak memaksa.

j) Selalu berjihad dalam kondisi bagaimanapun, dan mempunyai keyakinan bahwa Allah akan berpihak kepada yang benar dan memberikan petunjuk untuk itu (Kayo: 2007).

Supaya dakwah bisa diterima dengan baik oleh mad'u, maka diperlukan metode yang tepat dalam berdakwah. Metode dakwah adalah jalan atau cara untuk mencapai tujuan dakwah yang dilaksanakan secara efektif dan efisien (Helmi: 1973).

Metode dakwah dalam QS An Nahl 125:

Artinya: serulah (manusia) kepada jalan Tuhan-mu dengan hikmah dan pelajaran yang baik dan bantahlah mereka dengan cara yang baik. Sesungguhnya Tuhanmu Dialah yang lebih mengetahui tentang siapa yang tersesat dari jalan-Nya dan Dialah yang lebih mengetahui orang-orang yang mendapat petunjuk.(Departemen Agama RI: 2013).

Berdasarkan ayat tersebut terdapat metode dakwah yang akurat, kerangka dasar tentang metode dakwah yang terdapat dalam ayat tersebut adalah:

a. Bil al-Hikmah

Hikmah merupakan suatu metode pendekatan komunikasi yang dilaksanakan atas dasar persuasive (Amin: 2013).

b. Mauidloh Hasanah

Mauidloh hasanah atau nasehat yang baik adalah memberikan nasihat kepada orang lain dengan cara yang baik, yaitu petunjuk-petunjuk kearahkebaikan dengan bahasa yang baik, dapat diterima, berkenan dihati, menyentuh perasaan, lurus di fikiran, menghindari sikap kasar dan tidak mencari atau menyebut kesalahan objek dakwah sehingga pihak objek dakwah dengan rela hati dan atas kesadarannya dapat mengikuti ajaran yang disampaikan oleh pihak subjek dakwah (Muriah: 2000).

c. Mujadalah

Mujadalah adalah berdiskusi dengan cara yang baik dari cara-cara berdiskusi yang ada. Mujadalah merupakan cara terakhir yang digunakan untuk berdakwah yang digunakan untuk orang-orang yang taraf berfikirnya cukup maju dan kritis seperti ahli kitab yang memang telah memiliki bekal keagamaan dari para utusan sebelumnya (Muriah: 2000).

Sebagaimana adanya Da'i Profesional Abdul Karim Zaidan menghendaki kesempurnaan seorang pendakwah, yaitu pendakwah harusmemiliki pemahaman Islam yang mendalam, iman yang kokoh dan hubungan yang kuat dengan Allah (Zaidan: 1993). Ini menunjukkan bahwa seorang pendakwah hendaknya memenuhi kriteria sifat-sifat yang menjadi syaratsyarat seorang pendakwah yang baik.

Seorang pendakwah harus mampu melihat diri sendiri apakah dirinya sudah mampu melakukan dan mengerjakan syariat Islam secara benar, sehingga akan memudahkan dirinya untuk memberikan dakwah kepada orang lain. Seorang pendakwah (komunikator) harus mengetahui pesan apa yang harus disampaikan serta media dan cara apa yang akan digunakan untuk menyampaikan pesan tersebut sehingga pesan dakwahnya 
benar-benar mampu mencapai sasaran.

Kompetensida'ihendaknya mencakup aspek intelektual seperti kecerdasan, ilmu pengetahuan dan wawasan. Aspek karakter, seorang pendakwah hendaknya memiliki sifat-sifat mulia seperti keikhlasan, kejujuran,ketekunan, kesabaran serta keteladanan. Sedangkan kompetensi spritualnya, seorang pendakwahhendaknya orang yang teguh iman dan tekun ibadah. Kompetensi tersebut dapat mengangkat derajat dan kewibawaan seorang da'i di hadapan masyarakat dan dakwahnya akan diterima dan disukai. Firman Allah dalam surat al-Mujadalah ayat Al-Mujadalah ayat 11.

Artinya: Hai orang-orang beriman apabila kamu dikatakan kepadamu: "Berlapanglapanglah dalam majlis", Maka lapangkanlah niscaya Allah akan memberi kelapangan untukmu. dan apabila dikatakan: "Berdirilah kamu", Maka berdirilah, niscaya Allah akan meninggikan orang-orang yang beriman di antaramu dan orang-orang yang diberi ilmu pengetahuan beberapa derajat. dan Allah Maha Mengetahui apa yang kamu kerjakan. (Departemen Agama RI: 2013).

Ayat ini menunjukkan bahwa kompetensi iman, ilmu dan amal dapat meningkatkan derajat dan kewibawaan seseorang. Kewibawaan ini pada dasarnya menjadi faktor yang dapat membawa efektivitas dakwah. Sesuainya kata dan perbuatan menjadi keteladanan bagi masyarakat mad'u.

\section{Islam Moderat}

Islam Moderat berorientasi pada prinsip santun dalam bersikap, berinteraksi yang harmonis dalam masyarakat, mengedepankan perdamaian serta anti kekerasan dalam berdakwah. Ajaran ini memang selaras dengan kandungan utama Islam yang membawa misi Rahmatan Lil Alamin yaitu membawa rahmat bagi seluruh alam. Dalam hal ini menghargai pendapat serta menghormati adanya orang lain adalah sisi penting yang dibangun oleh Islam Moderat (Hilmi: 2016).

Pemaknaan Islam moderat memang sulit diterjemahkan karena pada zamanRasulullah SAW semua permasalahan diselesaikan berdasarkan pemikiran beliau sebagai pribadi yang cerdas dan selalu mendapatkan tuntunan langsung dari Allah SWT sehingga pada zaman sahabat hanya ada satu yaitu risalah Islamiyah Nabi Muhammad SAW. Sementara pada saat ini dimana zaman sudah berkembang dengan permasalahan yang semakin komplek, sehingga setiap pemaknaan didasarkan hasil pemikiran dan tafsir yang dilakukan oleh ulama. Penafsiran ulama ini sering kali berbeda dimana ada yang bergaris keras dan ada yang didasarkan pada logika secara bebas, oleh karena itu maka munculah moderasi Islam (Esposito: 2005).

Konsep Wasathiyah sepertinya menjadi garis pemisah dua hal yang berseberangan. Penengah ini diklaim tidak membenarkan adanya pemikiran radikal dalam agama, serta sebaliknya tidak membenarkan juga upaya mengabaikan kandungan al-Qur'an sebagai dasar hukum utama. Oleh karena itu, Wasathiyah ini lebih cenderung toleran serta tidak juga renggang dalam memaknai ajaran Islam.

Menurut Syaikh Yusuf Al-Qardhawi, Wasathiyah (pemahaman moderat) adalah salah satu karakteristik islam yang tidak dimiliki oleh Ideologi-ideologi lain. 
Sebagaimana dijelaskan dalam al-Qur'an:

$$
\text { وَكَذْلَكَ جَعَلْنَاكُمْ أُمََّة وَسَطًَا }
$$

Artinya : Dan demikianlah aku jadikan kalian sebagai Umat yang pertengahan (Departemen Agama RI: 2013).

Oleh karena itu maka ada pilihan untuk menjadi Islam yang moderat dan menentang segala bentuk pemikiran yang liberal dan radikal. Islam Liberal menitik beratkan pada nafsu dan akal logika dan hanya mendasarkan pada gagasan ilmiah saja. Islam Radikal memaknai secara tekstual dan kaku sehingga tidak dapat menyesuaikan dengan realitas hidup. Rasulullah menegaskan:Hindarilah sifat berlebihan dalam agama, karena Umat sebelum kalian hancur hanya karena sifat tersebut. (HR. Bukhari).

SubstansiajaranIslammengedepankan dakwah secara damai, ramah dan toleran. Karena pada dasarnya manusia diarahkan untuk berada di garis lurus tanpa pernah berlaku yang keras baik terhadap sesama muslim maupun non muslim. Gambaran moderat juga terdapat pada diri Rasulullah SAW yang tidak pernah mengusik penganut ajaran lain, berbuat dhalim maupun sikap yang lainnya. Bahkan lebih dari itu, beliau selalu mengajak para sahabat untuk selalu bersikap lemah lembut dan hidup rukun serta menjauhi bersikap kasar kepada orang lain.

Menurut Muhammad Imarah, Istilah Wasathiyah termasuk yang sering disalahartikan. Dalam bukunya, Ma'rakah al-Mushthalahat bayna al-Gharb wa al-Islam (Perang Terminologi Islam versus Barat). Beliau menjelaskan istilah al-Wasathiyah dalam pengertian Islam mencerminkan karakter dan jati diri yang khusus dimiliki oleh manhaj Islam dalam pemikiran dan kehidupan, dalam pandangan, pelaksanaan, dan penerapannya (Hilmy: 2012).

Jati diri manhaj Islam memang lebih cocok tertuang dalam ajaran al-Wasathiyah karena diantara doktrin yang ada, hanya moderat yang mampu mempraktikkan konsep Rahmatan Lil Alamin. Citra Islam dan umatnya akan terwujud lebih tepat jika dilihat pada konsep tersebut yang mana memadukan ajaran Qur'ani dengan entitas sosial kemasyarakatan.

Dalam konteks Indonesia, Islam Moderat yang mengimplementasikan Ummatan Wasathan terdapat pada dua golongan yaitu Nahdlatul Ulama (NU) dan Muhammadiyah. Keduanya mencerminkan ajaran Ahlussunnah wa al-Jama'ah yang mengakui toleransi serta kedamaian dalam berdakwah.

Sikap moderasi NU pada dasarnya tidak terlepas dariakidah Ahlusunnah wa alJama'ah (Aswaja) yang dapat digolongkan paham moderat. Dalam Anggaran Dasar NU dikatakan, bahwa NU sebagai Jam'iyah Diniyah Islamiyah berakidah Islam menurut paham Ahlussunah wa al-Jama'ah dengan mengakui mazhab empat, yaitu Hanafi, Maliki, Syafi'i, dan Hambali. Penjabaran secara terperinci, bahwa dalam bidang akidah, NU mengikuti paham Ahlussunah wa alJama'ah yang dipelopori oleh Imam Abu Hasan Al-Asy'ari, dan Imam Abu Mansyur Al-Maturidi. Dalam bidang fiqih, NU mengikuti jalan pendekatan (al-mazhab) dari Mazhab Abu Hanifah Al-Nu'man, Imam Malik ibn Anas, Imam Muhammad ibn Idris Al-Syafi'i dan Ahmad ibn Hanbali. Dalam bidang tasawuf mengikuti antara 
lain Imam al-Junaid al-Bagdadi dan Imam al-Ghazali, serta imam-imam yang lain (Qomar: 2002).

Bentuk Wasathiyah Nahdlatul Ulama diantaranya dengan menganut para imam sebagaimana disebut di atas, maka mereka semua berpaham Ahlussunnah wa alJama'ah yang selalu menjadi penengah atas berbagai paham yang ekstrim dan liberal. Menjalankan dakwah dengan lembut, ikut terlibat dalam aktivitas sosial serta merasuk ke berbagai struktur sosial mulai dari pedesaan sampai perkotaan.

Di kalangan Nahdliyin misalnya, terdapat banyak tokoh, pemikir, dan atau ulama yang dikenal memiliki karakter pemikiran moderat. Para tokoh moderat ini kebanyakan mengisi jajaran struktur kepengurusan di tingkat pusat atau Pengurus Besar (PB), baik di jajaran Majlis Syuro atau Dewan Tanfidz. Di antara nama-nama kiai NU yang bisa disebut sebagai tokoh moderat adalah $\mathrm{KH}$. Sahal Mahfudz, KH. Hasyim Muzadi, KH. Salahuddin Wahid, KH. Said Aqil Sirodj, KH. Masdar Farid Mas'udi, dan masih banyak lagi yang lain. Sementara itu, di kalangan Muhammadiyah, terdapat namanama seperti KH. Ahmad Dahlan, Hamka, Buya Syafi'i Ma'arif, Amin Ra'is, Din Syamsuddin, dan seterusnya, yang dikenal luas karena arus pemikiran moderatnya (Hilmy: 2012).

Lahirnya banyak tokoh yang memperjuangkan Islam Moderat, maka masyarakat lebih bisa menerimanya, sehingga dua golongan NU dan Muhammadiyah menjadi yang terbesar di tanah air ini. Kondisi ini cenderung menjadikan negeri ini lebih sejuk dalam setiap dakwahnya, hidup toleran, cinta damai. Oleh karena itu, Indonesia saat ini lebih ramai dengan berbagai majlis Taklim yang memiliki corak berbeda dengan negara lain bahkan diklaim sebagai corak Islam dunia yang sebenarnya.

Watak Moderat (Tawassuth) merupakan ciri Ahlussunah wa alJama'ah yang paling menonjol, disamping juga i'tidal (bersikap adil), tawazun (bersikap seimbang), dan tasamuh (bersikap toleran), sehingga ia menolak segala bentuk tindakan dan pemikiran yang ekstrim (tatharruf) yang dapat melahirkan penyimpangan dan penyelewengan dari ajaran Islam. Dalam pemikiran keagamaan, juga dikembangkan keseimbangan (jalan tengah) antara penggunaan wahyu (naqliyah) dan rasio ('aqliyah) sehingga dimungkinkan dapat terjadi akomodatif terhadap perubahanperubahan di masyarakat sepanjang tidak melawan doktrin-doktrin yang dogmatis. Masih sebagai konsekuensinya terhadap sikap moderat, Ahlussunah wa al-Jama'ah juga memiliki sikap-sikap yang lebih toleran terhadap tradisi dibanding dengan paham kelompok-kelompok Islam lainnya. Bagi Ahlussunah wa al-Jama'ah, mempertahankan tradisi memiliki makna penting dalam kehidupan keagamaan. Suatu tradisi tidak langsung dihapus seluruhnya, juga tidak diterima seluruhnya, tetapi berusaha secara bertahap di-Islamisasi.

Dalam konteks pemikiran keislaman di Indonesia, konsep moderatisme Islam memiliki sekurang-kurangnya lima karakteristik berikut ini. Pertama, ideologi non-kekerasan dalam mendakwahkan Islam. Kedua, mengadopsi pola kehidupan modern beserta seluruh derivasinya, seperti 
sains dan teknologi, demokrasi, HAM dan semacamnya. Ketiga, penggunaan pemikiran rasional dalam mendekati dan memahami ajaran Islam. Keempat, menggunakan pendekatan kontekstual dalam memahami sumber-sumber ajaran Islam. Kelima, penggunaan ijtihad dalam menetapkan hukum Islam (istinbat). Namun demikian, kelima karakteristik tersebut dapat diperluas menjadi beberapa karakteristik lagi seperti toleransi, harmoni dan kerjasama antar kelompok agama yang berbeda (Hilmy: 2012).

Moderatisme ajaran Islam yang sesuai dengan misi Rahmatan Lil 'Alamin, maka memang diperlukan sikap anti kekerasan dalam bersikap di kalangan masyarakat, memahami perbedaan yang mungkin terjadi, mengutamakan kontekstualisasi dalam memaknai ayat Ilahiyah, menggunakan istinbath untuk menerapkan hukum terkini serta menggunakan pendekatan Sains dan Teknologi untuk membenarkan dan mengatasi dinamika persoalan di masyarakat Indonesia.

Selayaknya perbedaan sikap menjadi sebuah dinamisasi kehidupan sosial yang menjadi bagian dari masyarakat yang madani. Keberadaan Islam Moderat cukup menjadi penjaga dan pengawal konsistensi Islam yang telah dibawa oleh Rasulullah SAW. Untuk mengembalikan citra Islam yang sebenarnya, maka diperlukan moderasi agar penganut lain dapat merasakan kebenaran ajaran Islam yang Rahmatan Lil 'Alamin.

\section{Da'i Moderat Millenial}

Era milenial adalah era yang ditanda'i antara lain oleh lahirnya generasi yang memiliki ciri-ciri: 1) suka dengan kebebasan;
2) senang melakukan personalisasi; 3) mengandalkan kecepatan informasi yang instan; 4) suka belajar; 5) bekerja dengan lingkungan inovatif; 6) aktif berkolaborasi, dan 7) hyper technology; 8) critical, yakni terbiasa berfikir out of the box, kaya ide dan gagasan; 9) Confidence, yakni mereka sangat percaya diri dan berani mengungkapkan pendapat tanpa ragu-ragu; 10) Connected, yakni merupakan generasi yang panda'i bersosialisasi, terutama dalam komunitas yang mereka ikuti; 11) berselancar di media sosial dan internet 12) sebagai akibat dari ketergantungan yang tinggi terhadap internet dan media sosial, mereka menjadi pribadi yang malas, tidak mendalam, tidak membumi, atau tidak bersosialisasi; 13) cenderung lemah dalam nilai-nilai kebersamaan, kegotong-royongan, kehangatan lingkungan dan kepedulian sosial; 14) cenderung bebas, kebarat-baratan dan tidak memperhatikan etik dan aturan formal, adat istiadat, serta tata krama.(Nata: 2016).

Generasi di era milenial memiliki sikap ketergantungan terhadap media sosial, sementara mereka belum dapat memilah dan memilih informasi yang di terimanya. Oleh karena itu da'i di era milenial perlu mempersiapkan diri dengan memperbaiki sikap dan kompetensinya, sehingga menjadi figur yang menginspirasi mad'u dan membawa rahmatan lil alamin.

Rahmatan lil alamin merupakan ciri keagungan Islam, yang penjabaran secara kongkrit diantaranya; orang lain ikut menikmatinya, merasakan faedahnya, terangkat martabatnya, siapapun membutuhkan-nya dan semua orang terbantu olehnya. Adapun nilai-nilai 
rahmatan lil alamin yang harus dimiliki da'i agar mampu membimbing generasi di era milenial, diantaranya, humanis, kerjasama (networking), sosial-profetik, toleransi dan pluralisme, keseimbangan, keteladanan, dialogis serta peningkatan kualitas sumber daya manusia. Baik secara normatif, filosofis dan historis, da'i moderat siap menghadapi era milenial. Yakni siap untuk menyiapkan sumber daya manusia yang dibutuhkan di era milenial, dan sekaligus dapat mengatasi berbagai problema kehidupan yang timbul di era tersebut.

Dengan munculnya teknologi mempermudah semua pengguna dalam mengakses informasi, yang membuat masyarakat menjadi kritis dan selektif yang menjadi tantangan bagi para da'i, disamping itu banyak masyarakat cepat bosan disaat mendengarkan ceramah yang membuat para da'i dituntut untuk tidak hanya fokus dalam menyampaikan secara serius tapi juga dituntut bagaimana para da'i dapat menyampaikan pesan yang penting dalam bentuk humor sehingga para da'i tidak membosankan ketika berceramah. Dengan begitu di era milenial untuk menarik perhatian masyarakat khususnys kaum muda para da'idituntut agar dapat menyampaikan pesan dalam bentuk menarik seperti menyelipkan humor, agar masyarakat tidak lagi berpikir bahwa belajar ilmu agama itu selalu kaku, tetapi masyarakat akan punya kesan bahwa belajar ilmu agama itu menyenangkan dan menarik, karena di era milenial terkhususnya kaum muda selalu mencari sesuatu yang menarik dan menyenangkan (Sugara dkk: 2019).
Teknologi sebagai media komunikasi sangat mendukung pelaksanaan dakwah. Dengan memaksimalkan media komunikasi dalam berdakwah, maka pesan dakwahakan lebih cepat diterima oleh banyak orang. Mengingat jarak yang terlalu luas, tidak mungkin dapat dijangkau da'i secara keseluruhan dengan menggunakan komunikasi langsung. Selain itu, pesanpesan dakwah yang hendak disampaikan akan lebih cepat diterima. Juga, dakwah bermedia akan terlihat lebih menarik karena kecenderungan banyak orang yang menyukai perangkat teknologinya seperti ponsel cerdas. Di samping karena tingginya kebutuhan akan informasi yang telah membuat ketergantungan dengan perangkat media. Maka dengan beberapa alasan tersebut, media sangat berperan dalam kegiatan penyampaian pesan dalam berdakwah.

Pengguna internet di Indonesia meningkat signifikan setiap tahun. KOMPAS.Com (19/02) merilis hasil survai dari Asosiasi Penyelenggara Jasa Internet Indonesia (APJII) merilis bahwa jumlah pengguna internet di Indonesia tahun 2017 mencapai 143,26 juta jiwa atau 54,68 persen dari total populasi Indonesia yang berjumlah 262 juta orang. Meningkat dibandingkan tahun 2016 yang mencapai 132,7 juta orang. Berdasarkan data tersebut, menarik pula dikaitkan dengan hasil survei CSIS sebanyak 81,7\% milenial memiliki Facebook, 70,3\% memiliki Whatsapp, $54,7 \%$ memiliki Instagram. Twitter sudah mulai ditinggalkan milenial, hanya 23,7\% yang masih sering mengaksesnya.Melalui internet, pesan dakwah dapat dengan mudah diakses oleh siapa saja sehingga manfaatnya dirasakan banyak orang. Maka, 
sesungguhnya internet menjadi media terbaik untuk menjangkau mad'u secara global, mengirimkan pesan ke lebih banyak pengguna, dengan biaya yang murah dan mampu mengomunikasikan informasi dalam waktu singkat. Banyaknya pengguna media sosial menjadi peluang meningkatkan jumlah penyerap pesandakwah (Habibi: 2018). Sehingga sebagai da'i milenial harus mampu mengikuti perkembangan zaman dengan memanfaatkan berbagai media dan mengikuti gaya anak-anak milenial sehingga pesan dakwah akan mudah diterima oleh anak milenial juga.

Terkait da'i milenial yang moderat, bagaimana dakwah yang disampaikan oleh da'ilebih berkesan menuju rahmatan lil alamin dan tidak berkesan mengarah kepada radikal. Sebagaimana wacana $\mathrm{KH}$. Ahmad Mustofa Bisri dalam tulisannya adalah jangan berlebihan. Kalimat ini memberi makna bahwa pola pikir yang digunakan oleh KH. Ahmad Mustofa Bisri adalah moderat, tidak ekstrim kanan atau ekstrim kiri. Kata moderat dikaitkan dengan satu kata kunci dalam tema toleran, satu kalimat kunci dalam tema seimbang serta satu kata kunci dalam tema adil.

1. Kata kunci dalam tema toleran

Dr (HC). KH. Ahmad Mustofa Bisri menggunakan kata bersaudara dalam tema toleran, karena semua manusia berasal dari bapak yang sama. Sehingga saling menghormati dan menghargai atas perbedaan pendapat. Orang yang tidak merasa bersaudara maka akan terjadi sikap berlebihan baik ektrim kanan maupun kiri. Di satu sisi sikap berlebihan berarti sangat fanatik dengan pendapat dan kelompok sendiri dan cenderung memusuhi dan merendahkan pendapat dan kelompok yang berbeda. Di sisi lain, terlalu menghargai pendapat dan kelompok orang lain, sehingga tidak memiliki jati diri dalam membela pendapat dan kelompok sendiri. Sedangkan diantara sikap keduanya, ada sikap tengah- tengah yaitu menghormati pendapat dan kelompok orang lain sekaligus membela, tanpa kehilangan eksistensi pendapat dan kelompok sendiri.

2. Kalimat kunci dalam tema seimbang

Dr (HC). KH. Ahmad Mustofa Bisri menggunakan kalimat kepentingan revolusi-ternyata tidak hanya memerlukan dalil aqli, tapi juga dalil naqli dalam tema seimbang, karena pentingnya seimbang dalam menggunakan dalil naqli dan 'aqli dalam memberikan nasehat kepada mitra dakwah. Jika tidak ada sifat "seimbang", maka akan terjadi sikap berlebihan baik ektrim kanan maupun kiri. Di satu sisi, sikap berlebihan berarti muslim yang memegang teguh teks-teks suci daripada akal. Di sisi lain, memberikan potensi akal sekuatkuatnya dalam menafsirkan teks-teks suci. Sedangkan diantara sikap keduanya, ada sikap tengah-tengah (seimbang) yaitu menyatukan antara teks-teks suci dan akal dalam meraih kebenaran.

3. Kata kunci dalam tema adil

Dr (HC). KH. Ahmad Mustofa Bisri menggunakan kata objektif dalam tema adil, agar seseorang memandang orang lain sesuai fakta, tanpa didasari oleh perasaan cinta dan benci. Jika tidak ada sifat objektif, maka akan terjadi sikap berlebihan baik ekstrim kanan maupun kiri. Di satu sisi, sikap berlebihan terlalu mencintai terhadap orang atau organisasi. Di sisi lainjuga terlalu membenci terhadap orang atau organisasi. 
Sementara di antara sikap keduanya, ada sikap tengah-tengah (objektif dan adil) yang tidak terlalu mencintai dan membenci. Jika bertentangan dengan kebenaran maka dibenci sikapnya, sementara jika sesuai dengan kebenaran maka didukung dan dicintai (Samsuriyanto: 2018).

\section{Kaderisasi Da'i di PCNU Kabupaten Kendal}

Organisasi Nahdlatul Ulama mensyaratkan kepada pendakwahnya yang ada di tengah masyarakat harus memberikan pencerahan yang lebih mengutamakan toleransi dan tidak mudah diprovokasi. Seorang da'i adalah pembela tauhid untuk itu setiap umat muslim memiliki kewajiban dalam berdakwah walaupun satu ayat. Namun, yang menjadi tantangan pendakwah saat ini adalah kurangnya dukungan media dan minimnya pengajaran agama Islam bagi generasi muda. Berdakwah di era milenial tidak harusmengunjungi beberapa tempat, tetapi lebih kepada berdakwah yang didukung media, baik elektronik dan cetak, Hal ini disadari benar oleh PCNU (Pengurus Cabang Nahdlatul Ulama') Kabupaten Kendal sehingga PCNU Kabupaten Kendal memberikan arahan kepada para da'i terutama da'i muda untuk dapat menggunakan berbagai media yang ada termasuk media sosial yang banyak digunakan oleh kaum melinial saat ini.

Hanya melalui media yang digunakan oleh kaum milenial tersebut yang bisa membuat para da'i untuk bisa masuk dalam kelompok milenial dan diteriam dengan baik. Sehingga para da'i muda khususnya akan bisa memberikan pencerahan kepada kaum milenial yang dituju sebagai sasaran dakwah.

Da'i muda ini juga diharapkan dapat muncul dari kaum terpelajar, sehingga bagi kaum terpelajar juga harus berhatihati dalam memilih organisasi yang dapat menaungi upaya dakwahnya. Pengurus PCNU Kabupaten Kendal menyarankan kepada kader-kader NU yang menempuh Pendidikan di Perguruan Tinggi untuk bisa selektif dalam memilih organisasi. Disampaikan bahwa kader muda Nahdlatul Ulama jangan salah pilih organisasi kampus. Pilih organisasi mahasiswa yang bernafaskan Ahlussunnah wal Jamaah Annahdliyyah. Hal ini dimaksudkan agar kader NU jangan sampai terpapar berbagai paham radikalisme yang sekarang sedang marak.

Tujuan pengkaderan da'i Lembaga Dakwah Nahdlatul Ulama (LDNU) disamping untuk meningkatkan kredibilitas da'i juga merupakan tempat untuk mendidik dan mencetak kader baik dilembaga formal maupun informal sehingga kedepan diharapkan para kader yang telah dididik tersebut dapat meneruskan bahkan mewujudkan tujuan dari Lembaga Dakwah Nahdatul Ulama (LDNU) sesuai dengan Aggaran Dasar dan Rumah Tangga Organisasi, untuk manfaat dari kaderisasi da'i dirasakan setiap kader akan perubahan yang baik dalam perilaku mereka dan semakin bertambahnya ilmuilmu yang bermanfaat untuk kehidupan mereka, dapat menyampaikan pesan Islam dan diterapkan dalam kehidupan seharihari.

Hasil pengkaderan da'i yang dilakukan Lembaga Dakwah Nahdatul Ulama (LDNU) bisa dilihat dari peningkatan 
kesiapan dan kesanggupan para kader dalam memberikan ilmunya kepada masyarakat, serta keberhasilanmereka pada bidang dakwah namun tetap saja kaderisasi ini memiliki kekurangan dan kelebihan tersendiri karena untuk melahirkan kaderkader yang professional dan berkredibilitas itu sangatsulit, maka hendaklah program kaderisasi yang dilakukan dengan jadwal yang lebih sering dan tidak hanya mengedepankan metode penyampaian saja namun juga harus lebih memperhatikan isi materi dakwah.

\section{Kesimpulan}

Di Era Milenial ini menjadi tantangan tersendiri bagi Kader Dakwah karena pada era ini pada pendakwah harus mampu menempatkan diri di tengah-tengah sosial masyarakat dengan kemajuan teknologi dan informasi. Pendakwah tidak hanya berdakwah melalui mimbar-mimbar formal saja namun harus mampu memanfaatkan media sosial yang ada, sehingga dakwah yang dilakukan dapat diberikan kepada setiap generasi yang disebut milenial.

Oleh karena itu kader dakwah harus mampu menyusun strategi yang efektif dalam menerapkan dakwah yang bisa mengena di semua kalangan. Kader Dakwah juga dituntut untuk dapat menyampaikan dakwah kapanpun dan dimanapun. Pada titik ini, seorang Kader Dakwah tidak bisa lagi hanya sebatas mahir berceramah, tetapi kader dakwah harus mampu berdiskusi, dan bahkan juga berdebat. Seorang pendakwah harus mahir literasi sehingga dapat menyebarkan dakwah dengan tulisan baik pada buku, koran, dan majalah, serta sampai penggunaan media sosial, blog, dan kanal-kanal media massa. Serta juga kemahiran konsultasi, demi dapat menjawab berbagai macam komentar yang menghampiri.

Supaya model dakwah yang dilakukan para da'i dapat dengan mudah diterima di kalangan milenial saat ini maka LDNU (Lembaga Dakwah Nahdlatul Ulama) Kabupaten Kendal mengadakan Kaderisasi Da'i Moderat Era Milenial yang bertema "Pelatihan Kader Penggerak NU", kaderisasi ini juga dipandu langsung oleh tim instruktur dari PBNU Jakarta. Kegiatan yang digelar di Pondok Pesantren Darul Qur'an Sukolilan, Patebon, Kendal yang diikuti sekitar 50 peserta berasal dari dua utusan MWCNU dari unsur syuriyah dan tanfidziyah serta dari lembaga, lajnah dan badan otonom ditingkat cabang. Pengkaderan ini bisa dilihat hasilnya dari peningkatankesiapandankesanggupanpara kader dalam memberikan ilmunya kepada masyarakat, serta keberhasilanmereka pada bidang dakwah di era milenial. 


\section{DAFTAR PUSTAKA}

Aliyudin AS, Enjang.(2009).Dasar-Dasar Ilmu Dakwah. Bandung: Widya Padjadjaran.

Amin, Samsuriyanto. (2018). Dakwah Moderat $\operatorname{Dr}(\mathrm{Hc})$. Kh. Ahmad Mustofa Bisridi Dunia Virtual. Tesis. Surabaya: UIN Sunan Ampel

Departemen Agama RI. (2013). Al-Qur'an dan Terjemahnya. Jakarta: Al-Fatih.

Esposito, John L. (2005). Moderate Muslims: A Mainstream of Modernists, Islamists, Conservatives, and Traditionalists, dalam American Journal of Islamic Social Sciences. (Vol. XXII). No. 3. Summer.

Habibi, Muhammad. (2018). Optimalisasi Dakwah Melalui Media Sosial Di Era Milenial.Artikel. Institut Agama Islam Negeri (IAIN) Pontianak.

Hasan, Noorhaidi. (2018). Literatur Keislaman Generasi Milenial Transmisi. Apropriasi.dan Kontestasi. Semarang: UIN Sunan Kalijaga Pres.

Helmy, Masdar. (2018). Dakwah dalam Alam Pembangunan. (Jilid. I). Semarang: CV Toha Putra.

Hilmi, Danial. (2016). Mengurai Islam Moderat sebagai Agen Rahmatan Lil 'Alamin. ISLAM MODERAT Konsepsi, Interpretasi, dan Aksi. UIN Malik Press.

K. P, Kayo. (2007). Manajemen Dakwah dari Dakwah Konvensional Menuju Dakwah Kontemporer. Jakarta: Sinar Grafika Offset.

Machasin. (2015). Psikologi Dakwah Suatu Pengantar Studi. Semarang: CV Karya Abadi Jaya.
Mahmud, Ali Abdul Halim. (1995).Fiqh al-Mas'uliyah fil-Islam.Kairo: Dar alTawzi' wa al-Nashr alIslamiyah.

Manajemen Pengkaderan Pengurus Besar PMII.(1998). Petunjuk dan Pelaksanaan Kader. Jakarta: Kabag Pengkaderan.

Masyhur, Syaikh Mustafa. (2000).Fiqih Dakwah. Jakarta: Al-I'tishom.

Moleong,Lexy. (2012). Metode Penelitian Kualitatif. Bandung: Remaja Rosdakarya.

Muhammad. (2018).Optimalisasi Dakwah Melalui Media Sosial Di Era Milenial. Artikel. Institut Agama Islam Negeri (IAIN) Pontianak.

Mulyana,Deddy.(2010). Metodologi Penelitian Kualitatif.Bandung: Remaja Rosdakarya.

Munawwir, AF. (1999). Kamus Al Bisri: Arab-Indonesia. Surabaya:Pustaka Progresif.

Munir, Samsul. (2018) Ilmu Dakwah. Cet II. Jakarta: Amzah,

Muniri. (2014).Kaderisasi Organisasi. Tulisan lepas disampaikan pada diklat

Muriah, Siti. (2000). Metode Dakwah Kontemporer. Yogyakarta: Mitra Pustaka.

Najamudin. (2010).Metode Dakwah Menurut Alqur'an. Yogyakarta: Pustaka Insan Madani.

Roki Sugara, Putri Adella Sari, Musnadi Muchsin, Attahira. (2019). Metode Dakwah Al Mauidza Hasanah Di Era Milenial. Artikel. Universitas Muslim Indonesia.

Stewart L. Tubs dan Silvia Moss. (1999). dikutip Jalaluddin Rakhmat dalam 
Psikolgi Komunikasi. Bandung: Remaja Rosdakarya.

Sugiyono. (2008). Memahami Penelitian Kualitatif. Bandung: Alfabeta.

Zaidan, Abdul Karim. (1993).Ushul adDa'wah Mu'assasah. Beirut: arRisalah.

Panindya, Belfast. Menjadi Generasi Millennial yang Selalu Kreatif, Aktif, dan Inovatif. https:// w w w. ko m pa sia n a.com / fast/5a598c1dbde5754d8c498382/ menjadi-generasi-millennial-yangselalu-kreatif-aktif-dan-inovatif. Diunduh pada 18 Nopember 2019

NUonline. Dipandu Instruktur PBNU, PCNU Kendal Siapkan Kader Militan. Sumber: https://www. nu.or.id/post/read/44205/ dipandu-instruktur-pbnu-pcnukendal-siapkan-kader-militan; Diunduh pada 19 Nopember 2019 Azmi,Nurazmi. Kebutuhan Dakwah Generasi Millennial (Nur Alhidayatillah). Artikel. UIN SUSKA Riau. 2019. https://uin-suska. ac.id/2017 / 10/30/ kebutuhandakwah-generasi-millennial-nuralhidayatillah/. Diunduh pada 18 Nopember 2019

Ananda, Rizqy Gusti. Genarasi Milenial dengan Berbagai Dampak Negatif dan Positif dari Sebuah Teknologi. Genarasi Milenial dengan Berbagai Dampak Negatif dan Positif dari Sebuah Teknologihttps:// w w w . k o m pa si a n a c o m 81/5b50c3ec5e1373602a7e07c7/ genarasi-millennial-denganberbagai-dampak-negative-danpositif-dari-sebuah-teknologi.
Diunduh pada 18 Nopember 2019

Widhiasmara,Yohanes. Dampak dari perkembangan teknologi di Era Globalisasi bagi PemudaSiswa. Kompasiana. https://www.kompasiana.com/ mara/5c0268fb43322f4d631176a5/ dampak-dari-perkembanganteknologi-di-era-globalisasi-bagipemuda-siswa? page=all. Diunduh pada 19 Nopember 2019 